\title{
OBITUARIES
}

\section{James McGill Souness FFA}

On 2nd September 1990 James Souness died in a climbing accident in the Alps and the Faculty lost a President of unusually wide experience and interests.

Born in Edinburgh in 1928 he was educated at George Heriot's School and started work as an actuarial student with the Caledonian Insurance Company. His career was interrupted by National Service in the Royal Navy and he qualified in 1956. That was the year of the Faculty's centenary and Mrs Souness, as the wife of one of the new Fellows, was called upon to present a bouquet to Mrs Weatherhead, the President's wife.

James Souness served the Faculty in many ways. He was an examiner and had two lengthy periods on Council, during the first of which he spent several years as Honorary Publicity Officer. His second spell on Council, tragically cut short, took him through several senior positions to his election as President in June 1989. He was deeply conscious of the honour and set out to give an energetic lead to the professsion in what he described as its pursuit of excellence.

His Presidential Address showed that he had a full grasp of all the many issues facing the profession - guidance, harmonisation, legislation and regulations. His own particular interests lay in the actuarial management of life offices and in the arguments about demutualisation and the reversionary bonuses of the traditional with-profits offices. He was convinced that the separate existence of the Faculty was a good thing for the profession in the United Kingdom, although he worked hard throughout the short time of his Presidency for the closest of co-operation with the Institute and was wont to remind his colleagues that the Faculty depended for its existence upon the continued strength of the Scottish life offices.

A year after qualifying he joined the Life Association of Scotland. He took a pioneering interest in the use of computers for actuarial work and, in 1961, chaired a Faculty working party on computers in life offices; he went on to become responsible for their development in his own office. In the late sixties he became involved in beating off hostile bids for his company's shares - and this led to its friendly take-over by Nationale Nederlanden. Over the years he had much contact with Holland and was appointed Honorary Dutch Consul in Edinburgh.

He became General Manger of the Life Association in 1974 and Managing Director nine years later. As chief executive of a life office based in Edinburgh he saw it as his duty to play an active part in the local Insurance Society and the local Chamber of Commerce, each of which elected him as its President. He served as Chairman of the Associated Scottish Life Offices and played his part in the committees of the Life Offices' Association and its successor, the Association of British Insurers, notably as Chairman of the working party investigating the effects of AIDS on life assurance mortality. 
Some may have seen James Souness as a demanding man, but he asked no more of others than he was prepared to give himself. He was a friendly person and his ready sense of humour was never far away, as many who heard his after-dinner speaking can confirm. He was a committed Christian, an elder and member of the choir in his Church, which he served in many ways. He maintained a lifelong connection with the Boys' Brigade and showed his concern for young people in his work as Finance Convener of the Royal Scottish Society for the Prevention of Cruelty to Children. He had a great zest for life, entering with enthusiasm and vigour into every activity; indeed activity, whether mental or physical, was a compulsion with him.

Jim had a natural talent for ball games. As a boy, it is said, he played rugby in the morning, football in the afternoon and table-tennis at night. His ability at soccer was noticed by Hibernian and he joined that famous Edinburgh club as a part-time professional. Perhaps the highlight of his footballing career came when he was a member of the Heart of Midlothian team which won the Scottish League Cup in 1955. At cricket he was capped three times for Scotland.

When his cricketing and footballing days came to an end, he maintained his obsession with fitness by taking up golf, where he quickly brought his handicap down to single figures, and by continuing to play the occasional game of tennis. Shortly afterwards he became interested in hill-walking and in 1984 he joined that small band of a few hundred people who have completed the ascent of all 277 Munros (Scottish mountains of over 3,000 feet). He enjoyed the exhilaration and freedom of the tops and was a good companion on the hills. Ever seeking greater challenges, he took up rockclimbing in Glencoe and on Ben Nevis and went on to climb Mont Blanc, the highest mountain in Europe. To mark his retirement from the Life Association he arranged to take his two sons on a climbing trip to Switzerland and it was there, just after reaching the summit of the Mönch, that he slipped and fell to his death.

Although modest about his artistic abilities, Jim Souness had an extensive memory of the works of the English poets and a great love of music. On his homeward drive after a day's climbing he liked nothing better than to listen to a Mozart piano concerto; he was Chairman of the Music Committee of the Scottish Arts Councils at the time of his death.

Above all, Jim Souness was a family man and he and his wife Ena got much joy from the achievements of their children and grandchildren.

W. M. M.

\section{John Leslie Anderson MA, FIA, FFA}

Leslie Anderson was a very talented man. He had a first class mathematical brain, an orderly mind, a very high work rate, an ability to make understandable the most confusing of problems and finally he had commonsense.

Born on 12 July 1904 at West Hartlepool of Scottish parents he was educated at Mill 